\title{
Asylbarn og menneskeverd: Etiske refleksjoner med utgangspunkt i erfaringer fra Helsesenteret for papirlose migranter
}

\author{
Sturla J. Stålsett \\ Stiftelsen Kirkens Bymisjon Oslo, sturla.stalsett@gmail.com
}

Asylbarns status og rettigheter $i$ Norge er $i$ kritisk søkelys. En sarlig utsatt gruppe er barn av papirløse foreldre som fødes på norske sykehus. Med bakgrunn i Kirkens Bymisjons arbeid med denne gruppen, argumenterer jeg i denne artikkelen for at slike eksempler viser at norsk offentlig politikk overfor disse barna tenderer mot å gradere og dermed underminere deres grunnleggende menneskeverd, slik dette blant annet kommer til uttrykk $i$ barnekonvensjonens krav om hensynet til barnets beste (artikkel 3). Ved hjelp av Judith Butlers tenkning om sårbarhet og «framing» samt Giorgio Agambens tenkning om «nakent liv» og unntakstilstanden, analyserer jeg hvordan denne graderingen av asylbarnas menneskeverd skjer. Til slutt viser jeg kort hvordan Helsesenteret uttrykker motstand mot disse mekanismene som bidrar til å underminere asylbarnas og de papirløses menneskeverd.

Nøkkelord: menneskeverd, asylbarn, papirløse i Norge, Kirkens Bymisjon, helsesenter, etikk, flyktninger, Judith Butler, Giorgio Agamben, diakonalt arbeid

English summary: Children of asylum seekers and human dignity: Ethical reflections based on the experiences of the Health Care Centre for Undocumented Migrants

The human rights and dignity of children of asylum seekers and undocumented migrants is much debated in Norway. A group that is particularly at risk is children born in Norwegian hospitals whose parents do not possess a legal residence permit. On the basis of the diaconal work of the Church City Mission in Oslo that aims at providing care and defending the rights of these groups through the Health Care Centre for Undocumented Migrants, the purpose of this article is to argue that the inherent human dignity of these children is being undermined in contemporary Norwegian politics. By relating to Judith Butler's thoughts on vulnerability and "framing» and Giorgio Agamben's theory of the "bare life» and the state of exception, the article aims at showing mechanisms that contribute to the undermining of the human dignity and rights of this group. The last part shows how the work of the health care center with its ethical and theological basis can be seen as offering resistance to these mechanisms and tendencies.

Keywords: human dignity, children of asylum seekers, undocumented migrants in Borway, Church City Mission, Health Care Center for Undocumented Migrants in Oslo, ethics refugees, Judith Butler, Giorgio Agamben, diaconal work 


\section{Praksis: Et helsesenter for papirlose migranter - mot myndighetenes onske ${ }^{1}$}

Vi vil ikke engang statistikkføre den nyfødte blant de utstøtte. Ikke bare usynliggjør vi de «ulovlige» voksne. Vi later også som deres nye barn ikke finnes. Å usynliggjøre er en mobbeteknikk som rammer enhver det gjelder. Et annet faktum er at vi også rammer oss selv og vårt samfunn ved at vi fratar oss verktøy for å utvikle kunnskap og forstålse om ethvert menneske som de facto bor her. Vi regner bare ikke med dem. ${ }^{2}$

Ingen vet hvor mange mennesker, voksne eller barn, som oppholder seg ulovlig i Norge. I 2008 anslo Statistisk sentralbyrå det samlede tallet til å være 18 000, men dette er bygget på usikre kalkyler. ${ }^{3}$ Vi vet også lite om denne gruppens faktiske levekår. Manglende kunnskap om mennesker som skjuler seg, er på mange måter naturlig. Men samtidig er uvitenheten også i noen tilfeller resultat av bevisst manglende registrering fra myndighetenes side. Det gjelder særlig, som vi skal se, en del barn av papirløse ${ }^{4}$ som fødes i Norge.

Høsten 2010 opprettet Kirkens Bymisjon og Røde Kors et helsesenter for papirløse migranter på ukjent adresse i Oslo. Det var det første tiltaket spesielt rettet mot denne gruppen her i landet. Tiltaket er støttet av en allianse av helsefaglige, juridiske og menneskerettslig orienterte miljøer, og har vel 100 frivillige medarbeidere i tillegg til de tre fast ansatte. Fram til 31. desember 2011 behandlet Helsesenteret $i$ alt 945 forskjellige pasienter fra 74 ulike land. 3400 medisinske konsultasjoner ble gitt. 32 prosent av pasientene var kvinner. Om lag tre fjerdedeler av de rapporterte helseplagene var av somatisk karakter, mens én fjerdedel hadde eksplisitt med psykisk helse å gjøre. Mange av pasientene hadde alvorlige psykiske lidelser som PTSL, angstlidelser, tunge depresjoner, psykoser og selvmordstanker. ${ }^{5}$

Helsesenteret behandlet i denne perioden i alt 43 barn. Mange barn fulgte også sine foreldre til senteret. De ansatte og frivillige ved senteret melder om bekymring for barnas situasjon. De møter engstelige og deprimerte barn, som lider direkte så vel som indirekte som en følge av foreldrenes situasjon.

Planene om å opprette et slikt helsesenter for papirløse migranter vakte sterk tverrpolitisk motstand. Regjeringen erklærte det direkte «uønsket». ${ }^{6}$ Da Kirkens Bymisjon og Røde Kors likevel åpnet Helsesenteret i oktober 2010, var dette derfor en klar utfordring til politiske myndigheter, selv om en formelt og juridisk ikke brøt loven.

Et eget utredningsarbeid la grunnlaget for Kirkens Bymisjons strategiske beslutning om å opprette tiltaket (Ottesen 2008). Siden denne innsatsen til fordel for papirløse migranter er politisk omstridt, er den etiske begrunnelsen for et slikt engasjement viktig.

Denne artikkelen vil klargjøre og utdype en slik normativ begrunnelse. Jeg vil drøfte status for asylbarnas og de papirløses menneskeverd i en norsk sammenheng, og tolke Helsesenteret som en etisk fundert innsats for å forsvare deres menneskeverd i praksis. I artikkelens første del argumenterer jeg for at den aktuelle politiske behandlingen av denne gruppen skaper en fundamental etisk uklarhet rundt deres status, som tenderer i retning av å gradere og dermed underminere menneskeverdet. I artikkelens andre del bringer jeg inn teoretiske perspektiver fra Judith Butler og Giorgio Agamben for å kaste lys over hvordan denne uklarheten oppstår. Til sist viser jeg relevansen av denne analysen 
for å forstå Helsesenterets virksomhet som etisk fundert forsvar for papirløses menneskeverd.

\section{Situasjonen: Asylpolitikk, menneskeverd og barnas beste}

\section{Asylbarn og tvangsreturer}

Våren 2012 kom de såkalte asylbarna i skarpt fokus i norsk offentlig debatt. Et kritisk søkelys ble satt på behandlingen av barn av asylsøkere som har fått endelig avslag og dermed skal returneres til sine opprinnelsesland, med tvang om nødvendig. Det er land mange av barna aldri har vært i. Per 1. mars 2012 bodde det ifølge tall fra Utlendingsdirektoratet 1173 barn og unge under 18 år i norske asylmottak. 410 av dem er født i Norge. 608 av barna er 5 år eller yngre, 330 er mellom 6 og 10 år, mens 235 er i alderen 11-17 år. ${ }^{7} 463$ barn var i den gruppen som skulle tvangsreturneres. ${ }^{8}$ Mange av dem var svært unge, og et flertall av dem var født i Norge: 166 av asylbarna var under 5 år gamle, og 103 av dem var norskfødte.

I løpet av 2011 reiste 6556 papirløse fra landet. Kun om lag hver fjerde reiste frivillig. 73 prosent ble uttransportert av norsk politi med tvang. ${ }^{9}$ En bred folkelig opinion, ikke minst i mange lokalsamfunn, engasjerte seg for barna. Kirkene og sivilsamfunnet mobiliserte kraftig. ${ }^{10}$

\section{Fodsler og (ikke-) registrering}

Debatten om asylbarna er en del av en økt oppmerksomhet om papirløse migranters kår i Norge generelt. I forbindelse med at det norske folketallet passerte 5 millioner i mars 2012, rettet ukeavisen Morgenbladet søkelyset mot et spesielt forhold knyttet til barn av papirløse foreldre i Norge (Vaaland 2012). Her beskrives en praksis der barn av foreldre uten gyldig oppholdstillatelse som fødes på norske sykehus, ikke registreres i Folkeregisteret. De nyfødte barna får en foreløpig journal og et nødnummer på sykehuset, som fjernes etter relativt kort tid. Informasjon oversendes Fødselregisteret og Folkeregisteret, men denne informasjonen blir ikke fulgt opp eller bevart, siden barnas foreldre ikke har lovlig opphold.

[...] den nye verdensborgeren med sine papirløse foreldre (vil) kun forbli registrert $\mathrm{i}$ en intern katalog på Bærum sykehus med sitt nødnummer. I den andre enden av informasjonskanalen forsvinner babyen helt ut av syne. Folkeregisteret har i dag ingen oversikt over barn som er født i Norge og blir værende i Norge, så lenge barnet blir født av papirløse. (Vaaland 2012)

Denne manglende registreringen innebærer at de ikke regnes med i statistikken. Norske myndigheter vet dermed offisielt ikke om disse barna, hvem de er, eller hvor mange de er. Barna får verken personnummer eller statsborgerskap - i noe land. For heller ikke foreldrenes tilhørighetsnasjon informeres om barnefødslene. Ifølge barnekonvensjonen $₫ 7$ har ethvert barn rett til navn og nasjonalitet umiddelbart etter fødselen. 
En slik praksis reiser grunnleggende etiske spørsmål, som i sin kjerne handler om disse barnas menneskeverd. Jeg vil argumentere for at viktige sider ved den aktuelle politiske behandlingen av asylbarn spesielt og papirløse migranter generelt i praksis innebærer at deres menneskeverd gjøres betinget, og dermed undermineres.

\section{Menneskeverd og sårbarhet}

Menneskeverd er en normativ, moralsk bestemmelse. Den uttrykker at ethvert menneske, utelukkende i kraft av å være menneske, har et iboende, ubetinget verd. Andre mennesker plikter å respektere dette verdet. Politiske myndigheter har ansvar for å beskytte det. Denne normen kan som kjent uttrykkes og begrunnes på ulike måter. I Menneskerettighetserklæringens artikkel 1 heter det at: «Alle mennesker er født frie og med samme menneskeverd og menneskerettigheter. De er utstyrt med fornuft og samvittighet og bør handle mot hverandre i brorskapets ånd.» Kantiansk etikk legger til grunn at ethvert menneske må sees som mål i seg selv, og ikke bare et middel. Begge disse begrunnelsene av menneskeverdet kan sies å ha røtter i kristen teologi, som tradisjonelt begrunner alle menneskers ukrenkelige verd $\mathrm{i}$ troen på at ethvert menneske er skapt $\mathrm{i}$ Guds bilde (jf. 1 Mos 1,27).

I samtidig teologi, særlig frigjøringsteologien, utfylles begrunnelsen med en forståelse av at det spesielt utsatte, sårbare menneskeliv (i bibelmaterialet paradigmatisk uttrykt $\mathrm{i}$ begreper som «farløse» og «enker», «fremmede» og «fattige») har et særlig krav på beskyttelse (se f.eks. Sobrino 1994; Tamez 1993; jf. Stålsett 2003). Nyere etisk teori har på liknende vis knyttet refleksjonen om menneskeverdets begrunnelse opp mot en fortolkning av fenomenet sårbarhet (se f.eks. Goodin 1985; Butler 2006, 2010, jf. nedenfor). Disse måtene å begrunne menneskeverdstanken på viser en særlig relevans i møte med papirløse flyktninger og asylbarn (se f.eks. Lysaker 2011).

\section{Menneskeverd og barns beste}

En indikasjon på at asylbarns og papirløses menneskeverd gjøres gradert og betinget, og at deres status som barn ikke veier like tungt som andre barns, er eksempelvis det forhold at enslige asylsøkere over 15 år fortsatt ikke er underlagt barnevernets omsorg, slik norsk lov krever for alle (andre) barn som ikke er under forsvarlig foreldreomsorg. Men også i andre henseender kan det synes som om myndighetene aksepterer et svekket rettsvern og dårligere faktiske livsvilkår for disse barna enn for andre barn. En test på hvor tungt barnets selvstendige menneskeverd veier i praktisk politikk, kan knyttes til en analyse av «barnets beste», som er et avgjørende prinsipp i FNs barnekonvensjon (artikkel 3). Det er rimelig å lese dette prinsippet som en konkretisering av barnets iboende menneskeverd, som i innledningen til barnekonvensjonen uttrykkes slik: «[A]nerkjennelsen av den iboende verdighet hos alle medlemmer av menneskeslekten og av deres like og uavhendelige rettigheter $[\ldots] . »$

I det politiske ordskiftet og i lov- og regelverket rundt asylpolitikken settes to hensyn opp mot hverandre: på den ene siden de humanitære hensyn, og på den andre siden inn- 
vandringspolitiske hensyn. Opphold på humanitært grunnlag kan innvilges, jf. utlendingsloven $₫ 38$, der det heter: «Det kan gis oppholdstillatelse selv om de øvrige vilkårene i loven ikke er oppfylt dersom det foreligger sterke menneskelige hensyn eller utlendingen har særlig tilknytning til riket.» I paragrafens annet ledd er barn særskilt behandlet: «I saker som berører barn, skal barnets beste være et grunnleggende hensyn. Barn kan gis oppholdstillatelse etter første ledd selv om situasjonen ikke har et slikt alvor at det ville blitt innvilget oppholdstillatelse til en voksen.» Imidlertid kan dette veies mot innvandringspolitiske hensyn, heter det videre: «Ved vurderingen av om tillatelse skal gis, kan det legges vekt på innvandringsregulerende hensyn, herunder a) mulige konsekvenser for omfanget av søknader på liknende grunnlag, b) de samfunnsmessige konsekvensene, c) hensynet til kontroll, og d) hensynet til respekten for lovens øvrige regler.» $(\$ 38$, annet ledd).

Det er verdt å merke seg vekslingen mellom «skal» og «kan» i denne paragrafen. Hensynet til barnas beste skal være et grunnleggende hensyn, heter det. Prinsippet om barnas beste er Norge er forpliktet på etter barnekonvensjonen artikkel 3 og artikkel 22 om flyktningbarn. Dette ble skjerpet til skal i den nye utlendingsloven, som trådte i kraft 1. januar 2010. Allikevel heter det altså fortsatt at det skal være et, ikke det grunnleggende hensyn. Og det kan settes til side av «innvandringsregulerende hensyn». Det kan med andre ord være tilfeller der det politiske behovet for å avgrense innvandringen vil kunne veie tyngre enn det enkelte asylbarnets ve og vel - til tross for barnekonvensjonens klare ord og bruken av «skal» i første ledd.

Dette er det avgjørende poenget i et brev fra Barneombudet datert 12. mars 2012, som fremmer en skarp kritikk av dagens asylpolitiske praksis (Barneombudet 2012). ${ }^{11}$ Under overskriften «Barnas beste og tilknytning til riket» uttrykkes særlig bekymring for de lengeværende barna, det vil si barn som bor i flere år med en uavklart situasjon på norske asylmottak. Over 400 barn har bodd i Norge i mer enn tre år uten avklaring, noen av dem har vært her i mer enn fem år. Barna bor i asylmottak, som er midlertidige botilbud til asylsøkere der tilbudet skal være «nøkternt». Barnas liv settes på vent, i en tilværelse som er preget av stor usikkerhet. Dette er en situasjon som er «svært skadelig for barna», skriver Barneombudet:

Uavhengig av om man mener at barna skal bli her eller reise til foreldrenes hjemland, er den behandlingen Norge gir de lengeværende barna svært skadelig for dem. Det er tilsynelatende full enighet om at det ikke er riktig at barna skal bære ansvaret for voksne menneskers valg og handlinger. Likevel tillater man at det skjer i dag. (Barneombudet 2012)

Barneombudet ber videre om at regjeringen «snarest mulig finner en løsning på den akutte situasjonen til de barna som har bodd her svært lenge uten lovlig opphold» og mener barna må få vurdert sine saker på nytt.

Det prinsipielle spørsmålet som Barneombudets brev reiser, er hvilken beskyttelse og status barns menneskeverd og prinsippet om barnets beste rent faktisk har, når dette i politisk praksis kan overkjøres av innvandringspolitiske hensyn. 
Ved vurderingen av om det foreligger sterke menneskelige hensyn etter utlendingslovens $₫ 38$, skal barnets tilknytning til riket tillegges særlig vekt. Barneombudet har fått tilgang til flere saker som tyder på en svært streng praksis i disse sakene. I saker der foreldrene har brutt utlendingsloven, for eksempel gjennom ulovlig opphold og arbeid, kan det virke som om det etter dagens praksis skal svært mye til før hensynet til barnet slår gjennom. Innvandringsregulerende hensyn av allmennpreventiv karakter tillegges svært stor vekt. (Barneombudet 2012)

I og med framleggelsen av St.meld. nr. 27 (2011-2012) Barn på flukt i juni 2012 foreslo regjeringen ingen endringer i loven på dette området, men varslet at hensynet til barns beste skulle veie tyngre i vurderingen av den enkelte sak. Mange tolket det som en følge av dette at 10 år gamle Yalda Bahadori vant fram i sin sak mot staten om opphold på humanitært grunnlag to måneder senere. Oslo tingrett konkluderte med at avslaget på søknad om opphold på humanitært grunnlag er ugyldig. I september 2012 ble det imidlertid klart at staten anker dommen.

\section{«Asylsøker» eller «barn»? «Papirlos» eller «returnekter»?}

I en komparativ analyse av asylsøkerbarnas status i Danmark og Norge viser Kathrine Vitus og Hilde Lidén (2010) at uklarheten eller spenningen mellom ulike hensyn preger disse barnas status i både norsk og dansk offentlig kontekst. Barna er fanget i to konkurrerende politiske identitetsdiskurser. Mens «asylsøker»-identiteten i dag er koblet opp mot kollektivt orienterte spørsmål om nasjonal sikkerhet, grenseovervåkning og velferdsstatens yteevne, handler den diskursive politiske identiteten rundt barn først og fremst om sårbarhet, behov for omsorg, beskyttelse og individuelle rettigheter.

Vitus og Lidén finner en tydelig forskjell mellom Danmark og Norge. Mens asylsøkeridentiteten helt har fått overskygge asylbarnas status som barn i Danmark, er bildet mer sammensatt og uavklart i Norge. I Danmark har barnekonvensjonen lav politisk status og gjennomslagskraft i det offentlige ordskiftet, og i den danske debatten om asylpolitikken spiller barns behov og rettigheter «en marginal rolle» (2010: 68). I Norge har beskyttelsen av barns rettigheter blitt koblet sterkt opp mot konstruksjonen av nasjonalt selvbilde, som siden 1980-årene har fått politiske og institusjonelle utslag som opprettelsen av et eget barneombud og generelt høy profil på barnepolitiske spørsmål, nasjonalt og internasjonalt. For tilfellet Norge konkluderer Vitus og Lidén med at barnerettigheter gis en mer universell og dermed overordnet status med hensyn til innvandringsregulering, men de understreker at dette kun gjelder diskursivt (Vitus \& Lidén 2010: 69). I politisk praksis ser de et annet bilde. I og med at barn som er i følge med foreldre eller familie ikke gis samme status som voksne når det gjelder selvstendig prøving av grunnlag for oppholdstillatelse, hevder Vitus og Lidén at Norge verken behandler asylsøkende barn som barn i tråd med barnekonvensjonen, eller som asylsøkere (2010: 78).

Spenningen kan ut fra Vitus og Lidéns analyse føres tilbake til en motsetning mellom hensynet til individuell menneskelig sårbarhet på den ene siden og samfunnsmessig sikkerhet på den andre. Alternativt kunne man se det som en avveining mellom to former for sårbarhet: barnets kroppslige, individuelle sårbarhet og en samfunnsmessig, systemisk sårbarhet. 
Denne grunnleggende spenningen speiles i språkbruken i den offentlige debatten. I diskursen om asylbarna utkjempes det en retorisk kamp der motbegrep utformes og anvendes. Selve uttrykket «asylbarn» inneholder som nevnt grunnmotsetningen mellom «barn» og «asylsøkere». Som motbegrep mot «papirløs» har norske myndigheter strategisk tatt i bruk begrepet «returnekter». ${ }^{12}$ Ansvaret for deres situasjon som papirløse, i myndighetenes øyne illegale eller ulovlige, skyves på denne måten tilbake på barnas foreldre. Migrantenes egne utsagn om at de frykter retur, framstår i denne terminologien utelukkende som en ulydighetshandling - de nekter. På spørsmål om det er rimelig å kalle barn for returnektere, framholder statssekretæren for asylsaker at hensynet til barna må vektes mot foreldrenes unnlatelser og faren for at myndighetene «gir incitamenter til juks». ${ }^{13}$

\section{Menneskeverdets forrang}

Denne analysen viser hvordan det i norsk politisk offentlighet er uklart hvorvidt og i hvilken grad asylbarnas og de papirløses menneskerettslige og barnerettslige beskyttelse faktisk gjelder. Nettopp i opprettholdelsen av en slik uklarhet tydeliggjøres forskjellen mellom disse barna og alle andre barn. Det hefter noe ved dem som gjør at de ikke helt kan regnes som barn. I mange tilfeller holdes barna ansvarlige for deres foreldres valg og (mis-)gjerninger. Dette er i direkte strid med barnekonvensjonen artikkel 2, annet ledd, som framholder at: «Partene skal treffe alle egnede tiltak for å sikre at barnet beskyttes mot enhver form for diskriminering eller straff på grunn av sine foreldres, sin verges eller familiemedlemmers stilling, virksomhet, meningsytringer eller tro.»

I politisk perspektiv står en her altså tilsynelatende overfor motstridende hensyn som veies mot hverandre. Poenget med å framholde menneskeverdets normative status er imidlertid at dette er etisk grunnprinsipp som ikke skal kunne tilsidesettes av andre politiske hensyn. Det markerer en grense for kollektivets og politikkens krav overfor den enkelte. Andre utenforliggende hensyn kan ikke gjøres gjeldende mot barns iboende menneskeverd, uten at dette verdet graderes og nedskrives. Det er derfor etisk problematisk når et prinsipp om barnets beste som er direkte forankret i barnets selvstendige menneskeverd, gjøres sidestilt med, og ofte underordnet, andre hensyn, som i dette tilfellet er definert som innvandringspolitiske.

Til dette kan det imidlertid sies at barnekonvensjonen selv framholder at barnets beste er «et», ikke «det», avgjørende hensyn. Her åpnes det med andre ord opp for andre hensyn. Dermed synes den etiske kritikken jeg anfører, ikke bare å ramme den aktuelle politiske praksis, men også å avdekke en mulig manglende stringens i forholdet mellom barns grunnleggende menneskeverd og prinsippet om barns beste i barnekonvensjonen.

For å motvirke tendensen til å underminere asylbarnas menneskeverd er det nødvendig å forstå bedre de mekanismene som bidrar til å skape og legitimere den påviste uklarheten rundt disse barnas menneskeverd i praksis. Til dette formålet vil jeg hente inn teoretiske perspektiver fra henholdsvis Judith Butler og Giorgio Agamben. 


\section{Analyse: Differensiert «sorg-barhet» og permanent «unntakstilstand»}

\section{Judith Butler: Sårbarhet og sorg-barhet}

Den amerikanske sosiologen og filosofen Judith Butler kan hjelpe oss til å få øye på hvordan disse barna framstilles, rammes inn, omtales, behandles og politiseres på måter som gjør at de ikke lenger helt er, eller teller/telles, som barn. Med utgangspunkt i det politiske og kulturelle reaksjonsmønsteret i USA etter terrorangrepene den 11. september $2001 \mathrm{og}$ den påfølgende krigen mot terror, utvikler Butler i bøkene Precarious Life (2006) og Frames of War (2010) en etisk tenkning om mennesket som kroppslig og sosialt konstituert. I kritisk oppgjør med USAs politiske reaksjon på supermaktens plutselig blottstilte sårbarhet i frykt (skarp opprustning av sikkerhetstiltak) og hevn (krigen mot terror), framholder hun at menneskelivet, ethvert menneskeliv, er ufrakommelig sårbart. Sårbarheten er riktignok ulikt fordelt, politisk og geografisk. I denne forskjellen ligger makten og dermed kimen til maktmisbruket, undertrykkelsen og utstøtelsen. Men sårbarheten er likevel et felles grunnvilkår. I det ligger det en mulighet. Når den anerkjennes som felles grunnvilkår, ulikt fordelt, kan nye rammer for politisk ansvar oppstå. Men det skjer ikke av seg selv. Her ligger den etiske forutsetningen for det politiske ansvaret, den etiske fordringen.

Denne tenkningen om sårbarhet er tydelig inspirert av Levinas' fenomenologiske filosofi/etikk. ${ }^{14}$ Originalt for Butlers tilnærming er at hun også bruker begrepet precarious for å uttrykke denne skjørheten, utsattheten og usikret-heten ved alt menneskeliv. ${ }^{15}$ Menneskelivet er «prekært» - det er noe truet, som det haster med å komme til unnsetning. Men det kan også framstilles mer nøkternt og likefram: At livet er "precarious», betyr at det krever at en del sosiale og økonomiske betingelser innfris for at det skal bli opprettholdt som liv (Butler 2010: 14).

Nært knyttet til tanken om sårbarhet og utsatthet er for Butler tanken om menneskelivets grievability, som direkte kanskje kunne oversettes «sorg-barhet». Det livet som er sårbart, gjenkjennes, anerkjennes og oppholdes som sårbart gjennom det faktum at det kan sørges over. Sorg-barhet er en betingelse for det liv som teller (Butler 2010: 14). Og det er her vi får øye på den kritiske rollen som innrammingen («frames/framing») spiller i Butlers teori. For også sorg-barheten fordeles ulikt. Enkeltes liv kan framstilles som liv det er poengløst å sørge over - det vil si at det tegnes eller representeres (innrammes) slik at når det går tapt, og til og med når det telles som tapt, teller det likevel ikke, siden det allerede er regnet som tapt. Det er framstilt som ungrievable.

Som eksempel bruker Butler sivile ofre på fiendens side i krig. "Vår» side vil gjerne framstille dem som uunngåelige tap, og derfor som allerede tapt før de ble drept. Sivile ofre i Afghanistan får sjelden noen minneord i avisene i vestlige land. I den offentlige dis-

kursen har de verken navn eller ansikter. De amerikanske ofrene for terror etter 11. september 2001 fikk derimot stor personlig oppmerksomhet. I israelske mediers rapportering fra Gaza-krigen var tallene av kvinner og barn som ble såret eller drept i israelske angrep, gjerne rammet inn med beskrivelse av disse som «levende skjold» for Hamas, påpeker Butler. I det øyeblikket disse framstilles som misbrukt av fienden, er de allerede 
tapt, og deres status som sivile, og som kvinner og barn, er blitt satt i parentes. Vi blir bedt om å tro at disse barna ikke egentlig er barn, og heller ikke egentlig i live (Butler 2010: xxvii). Deres liv er ikke sorg-bare, de er framstilt og oppfattet som ungrievable, for deres liv var, i ontologisk forstand og allerede fra starten av, ødelagt og tapt. De befinner seg i en fortapt og ødelagt sone. Når de blir ødelagt i krig, er ingenting egentlig ødelagt.

Denne strategiske og politiske framstillingen og fordelingen av sorg-barhet vil Butler avdekke (2010: xix). Hun ser den som intet mindre enn en voldelig uvirkeliggjøring av «den Andre» (Butler 2006: 33-34). For å avdekke dette må en klare å bryte dominerende former for representasjon og framstilling, slik at livets prekære sårbarhet kan bli oppfattet, og lagt til grunn for en alternativ etisk og politisk handling (2006: xviii).

Selv om det også er åpenbare forskjeller på sivile ofre i krigssoner og asylbarns status i en norsk kontekst i dag, kan Butlers fokus på sårbarhet og sorg-barhet, og sammenhengen mellom dem, kaste lys over debatten om asylbarna. Når barna i den politiske diskursen primært framstilles og behandles som asylsøkere, (barn av) «returnektere», eller som representanter for en stor gruppe som på ulike måter truer velferdsmodellen, den nasjonale sikkerhet eller asylinstituttet, blir de gjort ungrievable. De teller ikke som barn på samme måte som andre barn. Nasjonalstatens, velferdsmodellens, eller asylinstituttets antatte sårbarhet (innvandringspolitiske hensyn) får prioritet framfor barnets egen kroppslige og sosiale sårbarhet (humanitære hensyn). ${ }^{16}$

Barnet som fødes på et norsk sykehus for så bare å forsvinne ut av registrene, blir i denne politisk-administrative manøveren gjort ungrievable. Mer enn det: Den nyfødte blir ikke bare et barn det ikke gis grunn til å sørge over, men også et barn som det - ulikt alle andre nyfødte - ikke blir anledning til å glede seg over (jf. Butler 2010: 15).

\section{Giorgio Agamben: Nakent liv og unntakstilstanden}

Barna som ikke behandles som barn; den nyfødte som ikke får utløse glede og feiring; prinsippene, rutinene og lovene som egentlig gjelder, men bare ikke i disse spesielle tilfellene: Overfor slike situasjoner er det nærliggende å reflektere rundt kategorien unntak. Norske myndigheter ønsker å framstå med stor tyngde når det gjelder hensyn til barns velferd og rettigheter. Med bakgrunn i hva vi har sett her, kan en spørre om asylpolitikken derfor danner et unntak?

Giorgio Agambens tenkning om «nakent liv» (vita nuda), og unntakstilstanden kan på dette punktet ytterligere skjerpe blikket vårt i spørsmålet om den graderte og betingede politiske anerkjennelsen av asylbarnas menneskeverd, og rekkevidden av dette (Agamben 2005a, 2008, 2010). Når det i en demokratisk rettsstat som Norge kan synes politisk legitimt å sette parentes rundt eller forhandle om vekten av disse barnas menneskeverd, er dette i Agambens perspektiv ikke en tilfeldighet. Tvert imot vil han se dette som en utdefinering av de papirløse barna fra den sonen der lov og rett gjelder - det vil si, gjelder som beskyttelse, til deres fordel - som er symptomatisk. Det er ikke bare som symptom på den aktuelle politiske situasjon, der hele Europa står overfor «en stabil masse av innbyggere uten statsborgerskap som verken kan eller vil bli naturalisert, like lite som de vil bli repatriert» (Agamben 2008: 26). Han ser dette også som et tegn på en grunnskade 
eller selvmotsigelse i hele den vestlige, liberale rettstradisjon, der menneskerettighetene ofte sees på som selve kronen på verket. Menneskerettighetene, viser det seg, gjelder likevel ikke alle mennesker, hevder Agamben (2008). Når det kommer til stykket, gjelder disse universelle rettighetene bare for statsborgere:

I nasjonalstatens system viser de såkalt ukrenkelige og uomtvistelige menneskerettighetene seg å være blottet for enhver form for beskyttelse i det selvsamme øyeblikk det ikke lenger er mulig å oppfatte dem som rettigheter for borgerne av en stat. (Agamben 2008: 26)

I Menneskerettighetserklæringens første artikkel fastsettes menneskets verd som ukrenkelig, og likt for alle, allerede fra fødselen av: «Alle mennesker er født frie og med samme menneskeverd og menneskerettigheter.» Likevel er det først når denne fødselen innskrives i rammen av en nasjonalstat at dette verdet blir operasjonaliserbart, og dermed reelt. I begrepet «nasjon» ligger det allerede etymologisk en sammenheng mellom fødsel og stat, påpeker Agamben (2008: 27): «Nasjonalstat betyr: en stat som gjør fødselsrater og fødsel (altså det nakne menneskelivet) til grunnlag for egen suverenitet.»

På dette punktet følger Agamben opp den sene Foucaults analyser av biopolitikken, som handler om «hvordan makten konkret trenger inn i subjektenes kropper og deres livsformer» (Agamben 2010: 27). Originalt for Agambens analyse er at han ser det nakne, ubeskyttede menneskelivet som et produkt av den suverene makten, samtidig som den suverene makten konstitueres ved å produsere, det vil si stenge ute, dette nakne livet.

Det nakne livet inkluderes av loven, fanges under loven, ved å stenges ute fra dens beskyttelse. Makthaveren («suverenen») viser seg som lovens herre ved når som helst å kunne sette seg over den og erklære den ugyldig. Unntakstilstanden er dermed ikke bare en normaltilstand; den er også selve den tilstanden som lovens og rettens område funderes på. Men denne funderingen skjer altså på det nakne livets bekostning: «Unntakstilstanden, der det nakne livet var ekskludert fra og på samme tid fanget i rettsordenen, utgjorde sant å si, i kraft av sin særstilling, det skjulte fundamentet som hele det politiske systemet var basert på» (Agamben 2010: 31).

Denne analysen er for Agamben ikke først og fremst historisk. Den er aktuell i nåtiden. I vestlig politikk, fra Holocaust til Guantánamo Bay, er unntaket blitt regelen. «Leiren» - fra de groveste eksemplene til de tilsynelatende mer uskyldige: konsentrasjonsleire, interneringsinstitusjoner, asylmottak - er blitt det sentrale paradigmet på vår politiske situasjon. Her når Agambens analyse sitt mest kritiske punkt: Han hevder at vi lever i en permanent unntakstiltand, og at det er liten protest å spore.

I sin granskning av unntakstilstandens indre struktur og ytre konsekvenser i fortid og nåtid kommer Agamben også over et tilfelle der loven settes ut av kraft av barmhjertighet - ex dispensatione misericordiae (Agamben 2005a: 25f). Dette tilfellet viser etter Agambens syn en nødvendig åpning av loven, slik at det juridiske systemet ikke bare refererer til seg selv, men forholder seg til fakta «der ute» og har evne til og mulighet for å justere seg etter det. Den moderne unntakstilstanden følger imidlertid ikke dette mønsteret, men er i stedet et fors $ø \mathrm{k}$ på å «inkludere unntakstilfellet i den juridiske ordenen ved å skape en sone der det ikke lenger er mulig å skjelne mellom faktum og lov» (Agamben 2005a: 26, min oversettelse). ${ }^{17}$ 
Norsk asylpolitikk og behandlingen av asylbarn som «ikke helt» barn, og papirløse som «ikke helt» mennesker, kan i Agambens perspektiv sees som utslag av denne normaliserte unntakstilstanden. Med Agambens briller ville en kunne hevde at det er gjennom ekskluderingen av asylbarna og de papirløse at det politiske fellesskapet konstitueres og sikres. En ville videre kunne si at det er dette som skjer når velferdssamfunnets bærekraft eller eksempelets makt mot mulig juks prioriteres høyere enn beskyttelsen av noen bestemte barns grunnleggende, prekære livskår.

Spørsmålet om håndteringen av asylbarnas situasjon i norsk politikk handler i Agambens perspektiv også om karakteren og kvaliteten av hele det politiske systemet, om hva slags makt som virker i dette, og hva slags fellesskap som bygges - eller brytes ned - ved denne makten.

Det kan imidlertid være grunn til å stille spørsmål til en så vidtfavnende kritisk analyse. Det kan synes som om Agambens begreper om nakent liv og unntakstilstand beskriver nødvendige trekk ved ethvert politisk system. Hvis dét er tilfelle, kan det være vanskelig å se hvordan dette kan gjøres etisk relevant. Etikk forutsetter langt på vei at alternativer er mulige og ønskverdige. Videre må det innvendes at det synes som en overdrivelse å hevde at en slik unntakstilstand som den Agamben beskriver, er blitt noe som ikke bare tidvis oppstår, men som er permanent, og som konstituerer dagens politiske orden.

Selv om det er grunn til å hevde at barnas menneskeverd undergraves ved å graderes gjennom de mekanismene som her er beskrevet, betyr det ikke at gyldigheten av menneskeverdet og menneskerettighetene fullstendig oppheves i deres tilfelle. Det ville gitt myndighetene ubegrenset makt overfor de gruppene vi drøfter her.

Verken Butlers eller Agambens analytiske perspektiver kan brukes ukritisk eller i sin helhet, men jeg mener de hver for seg og samlet kaster lys over viktige mekanismer som skaper uklarhet rundt og dermed underminerer asylbarnas og de papirløses menneskeverd i praktisk politikk. Slik peker de også indirekte på hva som kan være effektive måter å motvirke disse mekanismene på.

\section{Tilbake til praksis: Helsesenteret som bekreftelse av asylbarns og papirloses menneskeverd}

Hvordan kan en etisk begrunnet praksis, som eksempelvis den som finner sted ved Helsesenteret for papirløse migranter, yte motstand mot undermineringen av det enkelte sårbare og sorg-bare asylbarnets verd og livsmulighet?

Med henvisning til Butler kan utfordringen i møte med asylbarn og papirløse fødsler formuleres som å bryte dominerende former for representasjon og framstilling, slik at livets prekære sårbarhet kan bli oppfattet, og politisk beskyttet (Butler 2006: xviii). Dette henger i det vesentlige sammen med fordringen som følger av vår lesning av Agamben, nemlig å synliggjøre og derigjennom bidra til å oppheve den permanente «unntakstilstanden» rundt disse gruppene, og gjenopprette lovens beskyttelse og menneskeverdets gyldighet og politiske kraft. Det kan ikke være en tilbakevending til den «første» lovens virkeområde, siden denne - hvis vi i dette følger Agamben - kun beskytter formalt men- 
nesket-som-statsborger. Det må være en beskyttelse som går lenger, som beskytter mennesket-som-kroppslig-sårbarhet, homo vulnerabilis.

Opprettelsen av Helsesenteret for papirløse migranter kan sees på som en handling som framholder menneskeverdets normative forrang mot politiske tendenser til å underminere dette for denne gruppen, og i særdeleshet for barna. Det skjer på flere måter. For det første viser fokuset på helse for en gruppe som til nå ikke fått oppfylt sine rettigheter eller fått tilrettelagte tilbud på helsefeltet, den nåtidige politiske relevansen av den begrunnelsen av menneskeverdet som knytter an til ethvert menneskes, i særlig grad utsatte menneskers, kroppslige sårbarhet.

For det andre uttrykker motstanden mot eller ulydigheten overfor klare, politiske signaler som opprettelsen av Helsesenteret innebar, en vilje til å oppheve den tilsynelatende unntakstilstanden som er opprettet rundt denne gruppen - som eksempelvis kommer til uttrykk i at asylbarn betraktes som asylsøkere mer enn som barn, og at barn av foreldre uten oppholdstillatelse ikke registreres på linje med andre barn. Med Agambens begrepsapparat kan vi si at opprettelsen av Helsesenteret var et forsøk på å oppheve negasjonen av menneskets ubetingede verd som innføres i lovens/politikkens erklæring av en unntakstilstand rundt disse barna. I den grad Helsesenterets praksis bryter med klare politiske føringer og utfordrer lovens grense på dette feltet, innebærer dette at en $n y$ unntakstilstand erklæres, der myndighetenes unntakstilstand «oppheves». Slik blir disse bestemte, utsatte menneskelivene - asylbarna, de papirløse migrantene - diskursivt og performativt rammet inn av en barmhjertighetens unntakstilstand (dispensatio misericordiae), som «åpner opp» loven og gir livet som kroppslig-sårbart absolutt forrang.

Med henvisning til Butlers påpekning av betydningen av «innrammingen» for muligheten av å oppdage og anerkjenne det sårbare og sorg-bare menneskelivet, kan virksomheten ved Helsesenteret, og den etiske og teologiske begrunnelsen for denne, representere en kritisk og alternativ framing av asylbarna. I den kristne, teologiske tradisjonen som inngår i det verdibaserte grunnlaget for Kirkens Bymisjons opprettelse av helsetilbudet, finnes for eksempel ressurser som kan brukes til å begrunne, motivere og operasjonalisere en slik 'unntakstilstand i unntakstilstanden'. Først og fremst vil det her være naturlig å vende seg til den kritikken av «loven» som har sitt utspring i evangeliene, som kraftfullt videreføres i de paulinske brevene, og som står sentralt i reformatorisk teologi og i nyere frigjøringsteologi. ${ }^{18}$

Helsesenteret arbeider med å avdekke, dokumentere og informere om den faktiske helsesituasjonen for denne gruppen. Slik skrives de inn i en «ramme» der disse barnas utsatthet gir dem et særlig krav på oppmerksomhet og beskyttelse. Den diakonale forankringen for Kirkens Bymisjons innsats i og gjennom Helsesenteret kan her by på alternative ressurser, kilder og forståelsesmåter som meldes inn i den diskursive striden som pågår rundt vekten av deres menneskeverd. Denne spesifikke verdiforankringen knyttet til et bestemt trosgrunnlags normer og narrativer kan slik fungere som et korrektiv til rådende politiske tenkemåter og begrunnelser. ${ }^{19}$

Det er liten tvil om at Helsesenteret for papirløse migranter, utover den konkrete helsehjelpen det har ytt, også har spilt en rolle for å utløse politiske debatter og prosesser rundt spørsmålet om asylpolitikk og menneskeverd i Norge. Mye av den politiske mot- 
standen mot dette tiltaket synes å være overvunnet. Skansene har flyttet seg. Noen endringer i politikken er innført, andre er varslet. Men disse endringenes omfang og langsiktige virkning er uklar. Den politiske striden er på ingen måte stilnet på feltet. Og stridens kjerne handler fortsatt om betydningen av asylbarns og papirløses menneskeverd i praksis.

\section{Noter}

1 En takk til min arbeidsgiver Stiftelsen Kirkens Bymisjon Oslo som innvilget forskningspermisjonen som har muliggjort arbeidet med denne artikkelen, og til University of Glasgow, Department for Theology and Religious Studies, hvor jeg var tilknyttet som gjesteforsker fra august 2011 til juni 2012. Jounalist, prest og tidligere generalsekretær i Radet for Psykisk Helse, Tor Øystein Vaaland (2012).

Humanitære organisasjoner opererer med 5000-10 000 personer, jf. Zhang (2008). På europeisk nivå regnet Social Sciences and Humanities Research Programme of the European Commission samme år med mellom 1,9 og 3,8 millioner personer som kunne karakteriseres som «irregular foreign resident population». Se: http://clandestino.eliamep.gr

4 Jeg bruker denne betegnelsen om mennesker som av ulike grunner ikke har dokumentert lovlig opphold i riket. Se f.eks.: http://papirlose.no/wp/?page_id=6 (jf. Ottesen 2008)

5 Likevel møtte Helsesenteret stengt dør i det øvrige helsevesenet for denne gruppen ved forsøk på viderehenvisning. Se Helsesenterets årsrapport 2010: http://bymisjon.no/no/Virksomheter/Helsesenteret-for-papirlose-migranter/Arsmelding

6 Om den unisone politiske motstanden mot planene, se Kjellberg og Rugeldal (2011: 101ff) og Stålsett (2011: 29-45).

7 Lastet ned 30. april 2012 fra: http://www.kommunal-rapport.no/artikkel/flere_enn_tusen_asylbarn_i_norge

8 Tall fra Utlendingsdirektoratet, gjengitt i Verdens Gang, 15. mars 2012.

9 Se Morgenbladet, 16. februar 2012: http://morgenbladet.no/samfunn/2012/kampen_om_asylet

10 Denne uttalelsen fra Flerkulturelt nettverk innen Norges kristne råd er representativ: «Det er uakseptabelt og umenneskelig å utvise etiopiske barn som har levd flere år i landet og har sterk tilknytning til Norge. Det er tydelig brudd både på FNs barnekonvensjon og prinsippet om at barns rettigheter ikke skal settes til side på grunn av foreldres valg. Barnas tilknytning til riket må prioriteres foran innvandringsregulerende hensyn. Vi ber derfor regjeringen om å ikke tvangsreturnere barna og deres familier.» Vedtatt på årsmøte 14. mars 2012, se: http://www.norkr.no/index.cfm?id=372963

11 Se http://www.barneombudet.no/brev/2012/lengeventendebarn

12 Statssekretær Pål Lønseth innrømmer overfor Morgenbladet 16. februar 2012 at det er han som har lansert begrepet' og gir grunner for dette: http://morgenbladet.no/samfunn/2012/kampen_om_asylet

13 «Mener regjeringen at barn som vokser opp i Norge, mange av dem er født her, også er returnektere?

- Det er vanskelig med barna. På den ene siden er de ikke selv ansvarlige for den situasjonen de er i. Men dette er et dilemma. Foreldrene har ansvaret for sin og barnas situasjon. De har fått sin rett, ved å få søke om beskyttelse, men unnlater å gjøre sin plikt som er å forlate landet når avslaget kommer. - Er det rimelig at barna skal betale prisen for foreldrenes handlinger?

- Vi skal ta hensyn til barna, men det hensynet må vektes blant annet mot faren for at vi gir incitamenter til id-juks. Veldig mange foreldre kommer til Norge med flere identiteter og ulike livshistorier.»

Intervju med Pål Lønseth i Stavanger Aftenblad, 12. januar 2012: http://www.aftenbladet.no/nyheter/ lokalt/--De-er-returnektere-2917382.html 
Se særlig Butler (2006: 128-151). Butlers tilretteleggelse har likhetstrekk med en form for «sårbarhets-etikk» som jeg har drøftet i bl.a. Stålsett (2007).

15 Etymologisk er «precarious» (prekært) en juridisk betegnelse for ‘̊ bli holdt gjennom en annens tjeneste', som sannsynligvis går tilbake til 1640-tallet. Ordet kommer fra latin precarius, 'oppnådd gjennom bønn eller forespørsel', fra prex (gen. precis) 'bønn'. Meningsinnholdet 'avhengig av en annens vilje' ledet etter hvert over til betydningen 'risikabel, farlig, usikker'. Se Online Etymology Dictionary: http://www.etymonline.com/index.php?term=precarious

16 Analogt med at en i krig beskylder fienden for å bruke kvinner og barn som menneskelige skjold, fremmes ofte argumentet at voksne asylsøkende skyver barna foran seg for å oppnå fordeler. Uansett om og når det skulle være hold i slik argumentasjon, er poenget her at det ikke under noen omstendighet kan belastes barnet.

17 «The modern state of exception is instead an attempt to include the exception itself within the juridical order by creating a zone of indistinction in which fact and law coincide.» (Agamben 2005a: 26).

18 Dette er ikke stedet for å utdype denne teologiske begrunnelsen. Men det bør bemerkes at den teologiske kritikken av «loven» også har vakt fornyet filosofisk og etisk interesse, bl.a. hos Agamben (2005b), men også hos Badiou og Brassier (2003) og hos Breton (2011). En særegen teologisk nyfortolkning av denne tradisjonen finnes også hos latinamerikanske frigjøringsteologer som Hinkelammert (1991), Sobrino (1994) og Tamez (1993).

19 I denne politiske drakampen er det ikke avgjørende om diskursene ansees for å være direkte «kompatible» eller ikke. Religiøst baserte ressurser og fortolkninger er med andre ord ikke i utgangspunktet diskvalifisert i møte med ikke-religiøse resonnementer og begrunnelser. Se f.eks. Jürgen Habermas' (2010) nyere tenkning om religionens plass i et liberalt samfunn.

\section{Litteratur}

Agamben, G. (2005a) State of exception. Chicago: University of Chicago Press.

Agamben, G. (2005b) The time that remains: A commentary on the letter to the Romans. Stanford, CA: Stanford University Press.

Agamben, G. (2008) Midler uten mål. Notater om politikk. Oslo: Cappelen Damm.

Agamben, G. (2010) Homo Sacer. Den suverene makten og det nakne livet. Kullebund: Valdisholm forlag.

Badiou, A. \& Brassier, R. (2003) Saint Paul: The foundation of universalism. Stanford, CA: Stanford University Press.

Barneombudet (2012) Barnas beste og tilknytning til riket. Oslo: Barneombudet.

Breton, S. (2011) A radical philosophy of Saint Paul. New York \& Chichester: Columbia University Press.

Butler, J. (2006) Precarious life: The powers of mourning and violence. London \& New York: Verso.

Butler, J. (2010) Frames of war: When is life grievable? London \& New York: Verso.Goodin, R.E. (1985) Protecting the Vulnerable: A Reanalysis of Our Social Responsibilities. Chicago: University of Chicago Press.

Habermas, J. (2010) An awareness of what is missing. I An Awareness of What is Missing. Faith and Reason in a Post-Secular Age, red. J. Habermas. Cambridge: Polity Press.

Hinkelammert, F.J. (1991) La fe de Abraham y el Edipo occidental. San José: Departamento Ecuménico de Investigaciones.

Kjellberg, J. \& Rugeldal, K. (2011) Illegal. Papirløs i Norge. Oslo: Spartacus.

Lysaker, O. (2011) Sårbar kropp - verdig liv: Anerkjennelseskampers eksistensielle kosmopolitikk. Oslo: Etikkprogrammet, Det humanistiske fakultet, Universitetet i Oslo. 
Ottesen, S.H. (2008) Papirløse migranter. En undersøkelse av situasjonen for mennesker uten lovlig opphold $i$ Norge, og humanitcere tiltak for denne gruppen i andre europeiske land. Oslo: Stiftelsen Kirkens Bymisjon.

Sobrino, J. (1994) The Principle of Mercy. Taking the Crucified People from the Cross. Maryknoll, NY: Orbis Books.

St.meld. nr. 27 (2011-2012) Barn på flukt. Oslo: Justis- og beredskapsdepartementet.

Stålsett, S.J. (2003) The crucified and the Crucified. A study in the Liberation Christology of Jon Sobrino. Bern, Berlin, Bruxelles, Frankfurt am Main, New York, Oxford \& Wien: Peter Lang.

Stålsett, S.J. (2007) The ethics of vulnerability, social inclusion and social capital Forum for development studies, 34, s. 45-62.

Stålsett S.J. (2011) Respekt. Se om igjen. Oslo: Pax forlag.

Tamez, E. (1993) The amnesty of grace: Justification by faith from a Latin American perspective. Nashville: Abingdon Press.

Vaaland, T.Ø. (2012) De synlige og de usynlige. Morgenbladet, 12. mars 2012. Lastet ned 30. april 2012 fra: http://morgenbladet.no/samfunn/2012/de_synlige_og_de_usynlige

Vitus, K. \& Liden, H. (2010) The status of the asylum-seeking child in Norway and Denmark: Comparing discourses, politics and practices. Journal of Refugee Studies, 23, s. 62-81.

Zhang, L.-C. (2008) Developing Methods for Determining the Number of Unauthorized Foreigners in Norway. Oslo: Statistisk sentralbyrå. 